\title{
Mongolia's Diplomatic Efforts to join the United Nations and the Changes in the Position of the Great Powers
}

\author{
Ulambayar Denzenlkham \\ Professor (Ph.D), Dean, School of International Relations and Social Studies, \\ University of the Humanities, Ulaanbaatar, MONGOLIA \\ ulambayar@humanities.mn
}

\begin{abstract}
This article discusses Mongolia's 15 years of diplomatic efforts to join the United Nations, the main factors that influenced it, and the changing policies and positions of the Soviet Union, the Kuomintang of China, the United States, and other great powers. Although the Mongolian People's Republic was able to join the United Nations in 1946, it was influenced by the Soviet Union's communist position. Since 1946, Chiang Kai-shek's Chinese policy and position have been a major obstacle. The history of the Republic of China, which existed on the mainland between 1912 and 1949, was the history of the struggle for power between the warlords, the history of the struggle between the Kuomintang and the Communists. In the nearly 40 years since the founding of the Republic of China in 1912, neither the warlords nor the Kuomintang have been able to exercise their sovereignty on the mainland, but they are keen to see Outer Mongolia as part of their territory. The Kuomintang was expelled from the mainland in 1949, shortly after 1946.

During the Korean War, initiated by Kim Il-sung, Joseph Stalin and Mao Zedong, Mongolia stood firmly behind North Korea, providing both moral and material support. It has not been mentioned anywhere that this resulted in Mongolia's efforts at the UN being postponed for many years. When Communist China entered the Korean War, the Kuomintang, which fully supported the US-led UN military operation (peacekeeping), not only continuously provoked at the Security Council of the United Nations, but also presented false documents about the MPR - described as "a Chinese territory seized by the Soviet Union” - sending troops to North Korea.
\end{abstract}

Received: 12 June, 2021; Accepted: 6 August, 2021

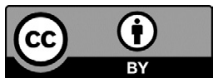


The United States, which has recognized the status quo of the Mongolian People's Republic, has made it clear that it has played an important role in the country's admission to the United Nations.

Thus Mongolia's attempt finally succeeded and it became the $101^{\text {st }}$ state to join the United Nations. As a consequence, Mongolia's independence has been approved by a recognize of Western powers and it began to emerge out of its isolation, participate in decision of global issues, and cooperate with the international community.

However, not only did this opportunity not be fully exploited, but due to the Cold War, Mongolia became a hotbed of ideological competition between the socialist and capitalist systems at the United Nations, the speakers' rostrum

Nevetheless,Post-Cold War, a whole new era of cooperation between Mongolia and the United Nations began.

Keywords: Independence, Security Council, General Assembly, United Nations, ambassador, membership, treaty, de facto and status quo

\section{Attempts of the MPR to join the UN}

It was 25 years since Mongolia gained its independence in 1921, signed a Treaty of Friendship with the Soviet Union on November 5, established diplomatic relations, adopted its first Constitution in 1924, and declared the People's Republic in a sovereign. Furthermore, Mongolia engaged with its two neighbors, both permanent members of the UNSecurity Council, by signing a new Treaty of Friendship and Mutual Assistance with the Soviet Union on 27 February 1946 and establishing diplomatic ties with the Republic of China (ROC or today's Taiwan) on 13 February 1946. Around 25 years had passed since, on 6 March 1946 the Mongolian leader marshal Khorloogiin Choibalsan recounted all these details in his written reply to
Georges Soriya, correspondent with the French newspaper Ce Soir in Moscow. ${ }^{1}$ The Mongolian leader reiterated these points in his written reply to Zhu Xingui, Moscow correspondent for the Chinese newspaper Central, sent the same day. ${ }^{2}$

In his letter of 21 June 1946 to Trygve H. Lie ${ }^{3}$, the UN's Secretary-General, the marshal Khorloogiin Choibalsan, who was simultaneously Prime Minister and Foreign Minister of Mongolia, wrote: "The government of this country maintains that it is appropriate to point out to the Security Council and its Assembly the fact that the people of the Mongolian People's Republic (MPR) have given material aid to our neighbor the Soviet Union and participated in the fight against the Fascist countries

\footnotetext{
The United Nations and Mongolia. Documents from the UN and Government Archives. (Collected Documents) UB.: 2008, No.10, pp. $72-73$

Trygve H. Lie, (1896-1968) Norwegian politician. He served as Norwegian Foreign Minister during the critical years of the Norwegian government in exile in London since 1940 to 1945. From 1946 to 1952 he was the first SecretaryGeneral of the United Nations. Lie earned a reputation as a pragmatic, determined politician.
} 
on the side of the United Nations. On 10 August 1945, the MPR announced and participated in the fight against Japan. The government of Mongolia sincerely hopes that the Security Council and the Assembly will not forget the contributions made by the Mongolian people in the United Nations' common endeavor and will approve the MPR's request to come a member of the United Nations' ${ }^{4}$ The letter expressed the MPR's readiness to take all responsibilities, as inscribed in the UN regulations, and to fulfil them.

A Committee appointed by the Security Council to recruit new members discussed the MPR's request on 6 August 1946. At the committee meeting that took place in New York the Chinese (Republic of China) ambassador to the UN Quo Tai-chi ${ }^{5}$ proposed to postpone the MPR's request for a year. According to him, the fact that MPR did not have diplomatic or consular relations with foreign countries, expect for the Soviet Union-though Mongolia had agreed to exchange ambassadors with Chinaproved that Mongolia was not ready to become a member of an international organization. He continued by arguing that to be sure that the MPR would be able to fulfil its duties towards the $\mathrm{UN}$, one should examine the case carefully. He also pointed out that its geographical remoteness cannot be the only reason why Mongolia did not have diplomatic relations with foreign countries. However, China, as a country which granted independence to the MPR, he contented, would happily support the MPR's request at a suitable time. In support of Mongolia, the Soviet ambassador to the UN Andrei A.Gromyko stated that: "The MPR is an independent young country that came into existence 25 years ago; it has contributed in the United Nations' war efforts; it was attacked by Japan prior to Pearl Harbor; it supported materially the Red Army in its war against fascist Germany by building a tank brigade and an aircraft escadrille, and financed them until the end of the war; it participated in the fight against Japanese militarism, and incurred damage worth 195 million tugriks (Mongolian currency) or US

\footnotetext{
Documents for the Foreign Policy of the MPR (1961-1961) Volume I, UB.: 1964, p. 109 (in Mongolian)

Quo Tai-chi (郭泰祺 1888-1952) was a diplomat during the ROC and an active member of the Kuomintang from the early years of the Republic of China until shortly after the fall of mainland China to the Communists. Graduated from the University of Pennsylvania in 1911, Ph.D Beta Kappa in 1914. He was one of the technical delegates of China to the Paris Peace Conference, 1918-1919. Quo Tai-chi held a variety of posts, including commissioner of foreign affairs of the "Canton government" in 1927 and Vice-Minister of Foreign Affairs of the ROC in the late 1920s and early 1930s. In 1929, he resigned the post of vice-minister of foreign affairs in protest of the placement of so many former imperial and warlord bureaucrats in the Kuomintang's Nanking Government, but was convinced to return. During one of his tenures as Vice-Minister, he was beaten by an angry, nationalist mob in Shanghai in May 1932 for his decision to sign an armistice with the Japanese, who were continuously pushing further into Chinese territory. He signed the armistice from the hospital, but resigned his post that year. From 1932 to 1940, Quo served as the first Chinese representative to Britain elevated from minister/legate to ambassador. While ambassador to Court of St. James, Quo also signed treaties of amity between the Republic of China and the republics of Latvia and Estonia. In April 1941, Quo was named to replace Wang Ch'ung-hui as foreign minister by the Central Executive Committee of the Kuomintang. During his time as foreign minister, he negotiated an end to the special, extraterritorial rights exercised by the United States and United Kingdom in China since the mid-19th century. Minister of Foreign Affairs since April 1941 to December 1941. Ambassador of the Republic of China to the United Nations since July 1946 to November 1947.
} 
$\$ 50$ million. I am astounded at China's proposal". ${ }^{6}$ The Polish ambassador, Oscar Lange, also voiced his astonishment at the Chinese proposal and pointed out that recognizing a particular country's independence has nothing to do with that country's acceptance into the UN membership. As the ambassadors of six countries, including China, the USA, and the UK, refused to clarify their position until further information was available on Mongolia, the Committee postponed the discussion of the MPR's request until the arrival of the Mongolian government delegation in New York. That is how the Mongolian delegation was invited by the Office of the Secretary-General of the UN. The invitation included four principal questions from the UN Security Council concerning Mongolia's foreign relations. $^{7}$

Large scale preparatory work followed. This included preparation of the following materials. Firstly, Dugersuren and Sodnomdondog from the Central Committee of the MPRP were to prepare materials concerning international issues. Secondly, Tserendorj and Choijil were to prepare materials on Mongolian history. Thirdly, Tseden was appointed to prepare materials on Soviet-Mongolian relations. Fourthly, Dugersuren was tasked to prepare materials on Mongolia during WWII, and fifthly, N.Lkhamsuren and B.Jargalsaikhan were to prepare materials on Mongolian-Japanese and Mongolian-Chinese relations. Other materials to be included were the decisions of the Atlanta, Tehran, Yalta and Potsdam Conferences; materials from the Dumbarton Oaks and San Francisco Conference; the UN rules; trade agreements; speeches of Franklin D.Roosevelt, Winston Churchill and Chiang Kai-shek; materials from the Paris Conference; decisions made at the Top Secret Agreement of February 11, 1945, signed by Marshal Stalin, Prime Minister Churchill and President Roosevelt, was classified as Top Secret, and was titled «Agreement Regarding Entry of the Soviet Union into the War against Japan»-concerning MPR's status quo; papers by Owen Lattimore and former vice president Henry A. Wallace; the Mongolian-Soviet treaties of 1921 and 1946, and much more. Business cards, a flag and passports for the Mongolian delegation were also to be prepared in both Mongolian and English. ${ }^{8}$

According to N.Lkhamsuren ${ }^{9}$, on the Soviet ambassador to Mongolia Ivan A. Ivanov's '10 "proposal" the Mongolian leader marshal Kh.Choibalsan appointed Yu. Tsedenbal, the General Secretary of the Mongolian People's Revolutionary Party, to head the Mongolian delegation. As head of the delegation, the latter was

\footnotetext{
The United Nations and Mongolia. Documents from the UN and Government Archives. (Collected Documents) UB.: 2008, p. 41

7 The United Nations and Mongolia. Documents from the UN and Government Archives. (Collected Documents) UB.: 2008, pp. 42-46

$8 \quad$ Ibid, pp. 32-36

9 Lkhamsuren N. (1917-1992) Educated in Agricultural insitute, Irkutsik in 1934-1938, USSR, Ph.D degree in Academy of Social Science under the Soviet Communist Party in 1956-59 in Moscow. Deputy Foreign Minister in 1946-1950, Foreign Minister of Mongolia in 1950-1954.

10 Иванов, Иван Алексеевич (1906-1948) Soviet Minister to Mongolia in 1939-1941 Soviet ambassador to Mongolia in 1941-1947, General major. Soviet ambassador to Afghanistan since 1948 and dead of illiness.
} 
also promoted to the position of First Deputy to the Prime Minister. Others in the Mongolian delegation were N.Lkhamsuren himself, the Deputy Foreign Minister, and B.Jargalsaikhan, a referent (foreign officer) from the same ministry. Upon the completion of the preparatory work in Moscow, the delegation flew to New York for the conference. On their way they called upon the Soviet Embassy in Paris to meet with Vyacheslav Molotov, Minister of Foreign Affairs, the USSR. The main topic of the conversation between Yu.Tsedenbal and V.Molotov was the newly independent Trans-Jordan (Kingdom of Jordan), which was a territory under the British Mandate. ${ }^{11}$

Upon their arrival in New York, the Mongolian delegation provided answers to the four main questions put forward by the Security Council of the UN.

On August 1946 the Security Council of the UN began to discuss requests for the UN membership from eight countries, including Albania, Mongolia, Afghanistan, Jordan, Ireland, Portugal, Iceland and Sweden.

When a general debate began on the admission of new member states, as the acting U.S. ambassador Herschel V.Johnson ${ }^{12}$ explained in detail the importance of using the principle of the universalism when admitting new member states. He said: "If the UN wishes to be successful, no country should stay outside, beyond the necessary period. Therefore, my government proposal to the UN that it take a longterm decision aimed at increasing its membership as much as it can in accordance with the $4^{\text {th }}$ paragraph of the UN Charter. Based on this, I propose that all the countries that have applied to the Council are to be admitted to the UN simultaneously ".13 Out of 11 member states at the Security Council (the number of members was than 11 rather than 15), the ambassadors of Brazil, Mexico, and Egypt supported the proposal, while the ambassador of Australia opposed. The UN Secretary-General, Trygve H. Lie, was among the support.

However, basing his argument on the principle of class differentiation, the Soviet ambassador, Andrei A.Gromyko, pointed to mistakes in the proposal of the U.S. ambassador, saying that, "countries should not be approached as if they are goods or products. The admission should not be based on a principle that sees all countries as having the same typology". ${ }^{14}$ $\mathrm{He}$ continued that each country had to be carefully assessed based on their individual circumstances, Alexander Cadogan, the British ambassador (he participated in the Yalta Conference in the capacity of Permanent Under-

11 Lkhamsuren N. Memory: Independence of the Motherland "Mongolian Worker" Newspaper. August 20, 1990 (in Mongolian)

12 Herschel Vespasian Johnson (1894-1966) was a U.S. diplomat from North Carolina. He was the great grandson of Governor Herschel Vespasian Johnson. Educated in University of North Carolina, Chapel Hill (B.A) and Harvard University (JD). He served as a U.S. Foreign Service Officer from 1921 to 1953, and his career included posts inEurope, Latin America and the UN.He served as Envoy Extraordinary and Minister Plenipotentiary to Sweden between 12 December 1941 and 28 April 1946. Thereafter, he served as the acting U.S. ambassador to the United Nations between 1946 and 1947. In 1948, he was appointed Ambassador Extraordinary and Plenipotentiary to Brazil.

13 The United Nations and Mongolia. Documents from the UN and Government Archives. (Collected Documents) UB.: 2008, Document No.3, p. 48

14 Ibid, Document No.3, p. 48 
Secretary for Foreign Affairs), said that he "had doubts regarding two applicant countries ", ${ }^{15}$ alluding to Mongolia and Albania. The ambassador of Holland, E.H. van Kleffens, reiterated the British ambassador's doubts.

When his proposal failed due to Soviet opposition, the U.S. ambassador changed his position by saying that the discussion of Mongolia and Albania's requests could be postponed without the Security Council's decision. The British ambassador also expressed the same position. Chiang Kai-shek's ambassador Tsiang Ting-Fu ${ }^{16}$ expressed China's readiness to support Mongolia, saying that his country had found Mongolia's reply to the UN Security Council's questions satisfactory. Afterwards, he contradicted himself by pointing out that "we were subject to aggression when the Mongols conquered China" and that "China is the country that granted independence to Mongolia", skipping the two hundred years of Qing DynastyChinese suppression of Mongolia .${ }^{17}$ While the USA was giving up on Mongolia due to Soviet opposition, the Republic of China (today's Taiwan) support for Mongolia was a sign of its duplicitous policy.

The only point that the British ambassador brought out was that Mongolia did not have enough experience in international relations and had diplomatic relations with only two countries. The USA had a clear proposal to admit all the countries to be UN which had requested admission, including Mongolia.

Had it desired Mongolia's admission to the UN, the Soviet Union would have supported the U.S. proposal based on the idea of universalism. It is clear that the Soviet ambassador was aware of the rules that no proposal gets through if only one of the five permanent members of the Security Council of the United Nations votes against it. It seems that it was strategically beneficial for the Soviet Union to block Mongolia's membership with the implication that Jordan would not be admitted to the UN either. When later in 1949 and 1950 the Soviet Union itself proposed to orchestrate admission based on the principle of universalism, it was too late. ${ }^{18}$

It should be noted, however, that France, which was a permanent member of the Security Council of the UN, proposed, without falling under the influence of other countries, to admit Mongolia. Therefore, it is possible to argue that France acknowledged

\footnotetext{
15 Ibid, Document No.3, p. 48

16 Tsiang Ting-Fu (蔣廷䊘 1895-1965) Tsiang was born in Shaoyang in Hunan Province. Tsiang's education from his teenage years had been Western and largely Christian, and he converted to Christianity at 11 . Having been urged to study in the US by his teacher from a missionary school, he was sent in 1911 to study in the United States, where he attended the Park Academy, Oberlin College and Columbia University. After obtaining a Ph.D., he returned to China in 1923, where he took up a position at Nankai University and then at Tsinghua University. Following mounting tensions in China's relations with Japan, Tsiang left academia in 1935 and joined the Chinese Nationalist government, which he served in many different capacities throughout the Sino-Japanese War. In 1945, Tsiang became the ambassador of China to the UN until July 1962, and he also served as the ambassador of China to the United States since January 1962. Following the establishment of the PRC on the Chinese mainland, Tsiang defended the exclusive right $\mathrm{f}$ the Taipeibased ROC to represent China in the UN and in the Security Council.

17 The United Nations and Mongolia. Documents from the UN and Government Archives. (Collected Documents) UB.: 2008, Document No.3, p. 50

18 FRUS. 1947, Vol. I, 1949, Vol. II, UN, 1955-57, Vol. XI.
} 
Mongolia de facto as early as $1946 .{ }^{19}$

When the question of Mongolia's admission to the UN was put to the vote, out of eleven member states of the Security Council of the UN six countries voted "for", including the Soviet Union, France, Republic of China, Poland, Mexico, and Brazil, three countries voted "against", including the U.S. the UK, and Holland, and two "abstained", that is, Australia, and Egypt. As two permanent member of the Security Council of the UN voted "against", Mongolia's request was declined.

Upon the return of the Mongolian delegation to Mongolia, Yu.Tsedenbal gave a big speech at a meeting of the MPRP activists entitled "The reasons why the Mongolian People's Republic has not been admitted to the UN" in which he criticized Western countries and praised the Soviet Union.

Between 1946 and 1961, Mongolia submitted membership requests four times and was discussed thirteen times at the UN. The second request, signed by marshal Kh.Choibalsan, was sent on 25 October 1948 and was discussed on the following dates: 16 June 1949, 19 December1951, 1 February 1952, 5 September 1952, November 1954, and in the autumn of $1955 .{ }^{20}$

Thethird request, signed by Yu. Tsedenbal, Chairman of the Council of Ministers, was sent to Dag Carl Hammarskjöld, the UN SecretaryGeneral. It reached the recipient on 14 September 1956 and was discussed at the UN on 12 December 1956. It was published in the article "The question concerning the admission of the Mongolia's People's Republic to the UN" in the Mongolian main newspaper Unen (Truth) on 4 September 1956.

The last request of 11 September 1957, signed by the Mongolian Foreign Minister S.Avarzed, was discussed at the UN on 9 September 1957. Mongolia's membership requests were continuously postponed mainly because of Chinese, American, and the Soviet oppositions.

During this period, France continued to support Mongolia, only abstaining on three occasions. In international juridical practice abstinence was not counted as protest. When we talk about France's de facto acceptance of Mongolia in 1946, we should also mention that at the Yalta Top Secret Agreement the USA and Britain had accepted Outer Mongolia's status quo. Later when Britain voted against Mongolia's admission to the UN, it did so because Mongolia "did not have enough international experience", whish does not mean that Britain denied Mongolia's existence as a country. The U.S. ambassador Herschel V. Johnson's statement that "We would not have put forward our proposal if there was a single country among the applicant countries which did not meet the requirements concerning both administrative organization and material wealth ", not only confirmed the USA's acceptance of Mongolia's status quo, but also showed

19 Ulambayar D. Foreign Relations between Mongolia and West: Past and Recent. UB.: 2004, p. 94 (in Mongolian)

20 Central Archives of Foreign Affairs, Mongolia. Fond.5 File. 25; The United Nations and Mongolia. Documents from the UN and Government archives. (Collected Documents) UB.: 2008, pp. 68-71, Церенцоодол П. Монгольская Народная Республика и Организация Объединённых Наций. УБ., 1958, стр. 70 
its intention to accept this de facto. ${ }^{21}$ Therefore, we can argue that the Soviet Union, the USA, the UK, France, and Republic of China had already accepted Mongolia's independence as early as 1946.

However, owing to the Baitag Bogd incident, ${ }^{22}$ when the Security Council of the UN was discussing Mongolia's request for membership on 18 July 1947 , the Republic of China, the USA, and the UK voted against. At a Security Council meeting on 7 April 1948 the Soviet ambassador tried to bargain by saying that if other countries voted for Albania and Mongolia, the Soviet Union would not vote against Jordan. The ROC, the USA, the UK, and France, however, did not accept this proposal. On 16 June 1949, the Security Council of the UN discussed the Soviet Union's next proposal regarding the admission of 12 countries which the ROC, and Canada voted against, and the USA, the UK, and France abstained for the first time. In 1952, the UK and France abstained.

At the $10^{\text {th }}$ General Assembly of the UN in 1955, Canada's proposal to admit 18 countries, including the MPR and Japan to the United Nations on the principles of universalism was considered at the Security Council of the United Nations. At that time, Chiang Kai-shek's China proposed to the UN Security Council that join 11 of the 18 countries, including admit new candidatures South
Korea and South Vietnam. The Soviet Union rejected "veto" to the Kuomintang proposal, because they did not recognize that South Korea and South Vietnam. The Kuomintang's ambassador to the UN, Tsiang Tingfu, has the right to imposed "veto" on Mongolia and Japan.

Earlier, in October 1949, Government of the MPR established diplomatic ties with the newly formed communist China as a result of the democratic revolution and broken with the ROC. Sino-Soviet Treaty of Friendship and Alliance of August 14, 1945, was also annulled by the Kuomintang government in 1953. The agreement included the recognition of the MPR by the Government of the Kuomintang. At the 10th Session of the UN General Assembly in 1955, Turkey was one of 52 countries that adopted a draft resolution on the simultaneous admission of all 18 countries, including the Mongolian People's Republic. Belgium, France, Greece, Israel, and the United States abstained, while Cuba and the Kuomintang refused. In the UN Security Council, the permanent members of the Soviet Union, France and the United Kingdom voted in favour, while the United States abstained and the Kuomintang China rejected "veto". ${ }^{23}$

During the 1956 vote the USA, the UK, and France abstained. During voting at the Security Council on 9 September 1957 the UK and France abstained.

21 The United Nations and Mongolia. Documents from the UN and Government Archives. (Collected Documents) UB.: 2008, Document No.3, p. 48

22 The Battle of Baitag Bogd Mountain or Beitashan Incident (北塔山事件) was a border conflict between ROC, MPR, and the USSR. The Mongolian People's Republic became involved in a border dispute with the Republic of China, as a Chinese Muslim Hui cavalry regiment was sent by the Chinese government to attack Mongol and Soviet positions. There had always been a Xinjiang police station manned by a Chinese police force with Chinese sentry posts before and after 1945.

23 Resolutions and Decisions adopted by the General Assembly during its 10th session: GA Official Records, 10th session, Supplement No. 19 Resolutions and Decisions, 20 September - 20 December 1955: A/3116 


\section{The MPR joined the United Nations}

When a number of newly independent the UN member states questioned the ROC's right of representation at the UN on 25 October 1961 the Security Council discussed Mongolia and Mauritania's requests for membership. The Soviet ambassador Valerian A. Zorin called on the Security Council to approve the Soviet proposal regarding the admission of Mongolia to the UN. Afterwards, Nathan Barnes, the ambassador of Liberia, which was not a permanent member of the Security Council of the UN, expressed his support of Mongolia.

The ROC Deputy Permanent Representative to the UN, Hsueh Yu$\mathrm{chi}^{24}$ said groundless things, such as that Mongolia had been inseparable from China since the XIII century. He concluded his speech by staying that, to support Mauritania, he would not participate in the voting concerning Mongolia. As at that time its representation in the Security Council of the UN was under question, ROC did not participate in the voting.
The U.S. Minister, Deputy Permanent Representative to the UN, Yost, Charles. W, ${ }^{25}$ said that he would abstain in order to "clear the way" for Mongolia's admission to the UN in the future. In this way, the U.S. and ROC agreed between themselves at the level of Deputy Permanent Representatives on the Mongolian question, with Hsueh not participating in the voting and Yost, Charles. W, abstaining. The U.S. Permanent Presentative at that time was Adlai Ewing Stevenson. ${ }^{26}$

The French ambassador, Armand Berard, had never opposed Mongolia's candidature. At some voting sessions he abstained, in others he voted in favour of Mongolia. According to him, this act of support showed the French ambassador's approval of Mongolia's wish for independence. He also expressed the hope that institutions in Mongolia would develop in democratic ways.

Following detailed research, Sir Patrick Dean, the UK ambassador, said that he decided to support Mongolia. He

${ }_{24}$ Y.C.Hsueh. Minister, Deputy Permanent Representative of the ROC to the UN in 1960-1964, Ph.D, Ambassador to Canada since1964 to 1970, ambassador to Spain in 1970-1972.

25 Charles Woodruff Yost (1907-1981) was a career U.S. Ambassador who was assigned as his country's ambassador to the UN since 1969 to 1971. Charles W.Yost was born in Watertown, New York.. He attended the Hotchkiss School, where he was a member of the class of 1924 that included Roswell Gilpatric and Paul Nitze, before graduating from Princeton University in 1928. He did postgraduate studies in Paris. Over the next year he traveled to Geneva, Berlin, the Soviet Union, Poland, Rumania, Hungary, Yugoslavia, Spain, and Vienna.Yost joined the U.S. Foreign Service in 1930 on the advice of former Secretary of State Robert Lansing, and served in Alexandria, Egypt as a consular officer, followed by an assignment in Poland. In 1933 he left the Foreign Service to pursue a career as a freelance foreign correspondent in Europe and a writer in New York. He attended the Dumbarton Oaks Conference from August to October 1944, when he worked on Chapters VI and VII of the UN Charter. He then served at the UN Conference on International Organization in San Francisco in April 1945 as aide to Secretary of State Edward Stettinius. In July of that year he was secretary-general of the Potsdam Conference.Acting ambassador to Thailand January-June 1946, ambassador to Laos in 1954-1956, ambassador to Syria in January-February 1958, ambassador to Morocco in 19581961, 9th ambassador to the UN in 1969-1971.

26 Adlai Ewing Stevenson II (1900-1965) was an American lawyer, politician, and diplomat. President John F. Kennedy was elected, he appointed Adlai E.Stevenson as the United States ambassador to the UN. Adlai E. Stevenson served from 1961 until his death in 1965 from a heart attack in London, following a United Nations conference in Switzerland. 
also added that he had neither enough evidence of Mongolia's independence nor a firm proof to the contrary. "We took into consideration the fact," he continued, "that several countries that we respect, including India, have already recognized Mongolia's independence by establishing diplomatic relations".

Afterwards, the ambassador of the United Arab Emirates Omar Loutfu, and the ambassador of Ceylon (Today's Sri-Lanka) T.B.Subasinghe, made long speeches in support of Mongolia. In the same vein the ambassador of Ecuador Leopoldo Benites Vinueza, the Chilean Daniel Schweitzer, and the Turkish ambassador and President of the Security Council Rifat Turgut Menemencioglu explained their decision to support Mongolia. At that point it became clear that 11 members of the Security Council would vote for the proposal to admit Mongolia. ${ }^{27}$ On the other hand, in the autumn of 1961, Turkey chaired the Security Council of the United Nations. ${ }^{28}$ Turkey supported Mongolia during its 1955 presidency of the Security Council. ${ }^{29}$

As during the voting nine members voted in favour, the USA abstained, and the Chiang Kai-shek's China did not participate, the Rifat Turgut Menemencioglu, President of the Security Council, ambassador of Turkey announced the question regarding Mongolia's admission being decided by the majority of the vote, and recommended the Security Council's decision to the General Assembly of the United Nations. At the time the UN Acting Secretary-General was U Thant, Burma's ambassador, who took the post following his predecessor Dag Hammarskjöld's death in a plane crash in northern Rhodesia (today's Zambia) at the end of September 1961.

When the members of the Security Council expressed their positions regarding Mauritania and proceeded to vote, the United Arab Emirates voted against, the Soviet Union abstained, and 9 other countries voted in favour of Mauritania.

On 27 October 1961 during the $16^{\text {th }}$ General Assembly of the UN 23 countries submitted a proposal to admit Mongolia to the UN, which was decided in favour of Mongolia without voting. Thus Mongolia's attempt finally succeeded and it became the $101^{\text {st }}$ state to join this international organization. As a consequence, Mongolia's independence has been approved by a host of Western powers and it began to emerge out of its isolation, participate in decision of global problems, and cooperate with the international community.

\footnotetext{
7 FRUS. 1961, UN, 1961-63,Vol. XXII, Официальные отчёты Генерального Ассамблея: XVI сессия пленарного заседания (1-11). Стенографические отчёты заседания, Нью Йорк.: 19 октября-15 декабря 1961

28 Presidents of the Security Council : 1960-1969, un.org.

29 Ulambayar D. «Mongolian-Turkish Relations: From De Facto till De jure»-Journal of East Asian Studies in Türkiye Doğu Asya Araştırmaları Dergisi. 土耳其东亚研究学刊 DAAD GÜZ Fall 2020 (in turkish, english \& chinese) ISSN: 2587-1919, E-ISSN:2619-953X impact factor journal. pp. 131-147
} 


\section{Conclusion}

As the UN is an international organization of independent countries, any question regarding the admission of a certain country to its membership is discussed at the Security Council and the General Assembly of the United Nations. According to international judicial anddiplomatic conventions, voted "in favour" imply the de facto approval of the country under consideration. It is also referred to as "collective approval".

It is known that, following the victory of the Chinese Communist Revolution, in 1950 the UK severed its diplomatic relations with the Republic of China which were established in 1928. During that time the UK normalized its relations with the People's Republic of China. It should be noted that, as a consequence, the UK at that time also became free of pressure from the ROC.

Owing the Cold War, when the UN turned into a platform of struggle between the two opposing systems and ideologies, Mongolia not only could not utilize the above-mentioned possibilities, but also got drawn into this ideological conflict.

In his work based on American foreign sources, the Mongolian scholar, diplomat Dr. R.Bold concluded that the USA was synchronizing its foreign policy with Taiwan regarding Mongolia's admission to the UN. R.Bold wrote about many things: how Taiwan's vote against Mongolia was tantamount to being against the countries that supported Mongolia, which, resulted in the questioning of Taiwan's rights of representation at the UN; how a host of independent countries lost their chance of being admitted to the UN because of some countries opposition to Mongolia; how the American ambassador became tired of his country's baseless opposition to Mongolia; how Mongolia could not get its name mentioned in the resolution of the Bandung Conference of Asian and African counties, and how political pressure had been exerted on Chiang Kai-shek, who ignored the American policy, despite the fact that Taiwan existed thanks to the latter's support. According to R.Bold, the USA President and Chiang Kai-shek also agreed on the following: "In order not to oppose Mongolia's candidature, the USA will abstain from voting; the USA will make an announcement in support of Taiwan; President John Kennedy will give an assurance to Chiang Kai-shek through diplomatic channels that the USA will vote against Communist China's admission to the UN; in this case Taiwan will not vote against Outer Mongolia. R.Bold concluded by reiterating the fact that the USA's support for Mongolia's admission to the UN was a continuation of its policy of recognition of Mongolia. ${ }^{30}$ It is clear that the USA played a crucial role in Mongolia's admission to the UN.

In 1949, 1955 and 1956 the USA abstained from voting when discussions were carried out around the principle of universalism. Nevertheless, It should be noted that Mongolia had lost the golden opportunity of getting admitted to the United Nations in 1946, which was influenced by the communist position of the Soviet Union.

The history of the Republic of

30 Bold R. Mongolian Independent and the USA (1910-1973). UB.: 2008, pp. 268-269 (in Mongolian) 
China, which existed on the mainland between 1912 and 1949, was the history of the struggle for power between the local warlords, the history of the struggle between the Kuomintang and the Communists. In the nearly 40 years since the founding of the People's Republic of China in 1912, neither the warlords nor the Kuomintang have been able to exercise their sovereignty on the mainland, but they are keen to see Outer Mongolia as part of their territory. The Kuomintang was expelled from the mainland in 1949, shortly after 1946.

During the Korean War, initiated by Kim Il-sung, Joseph Stalin and Mao Zedong, Mongolia stood firmly behind North Korea, providing both moral and material support. It has not been mentioned anywhere that this resulted in Mongolia's efforts at the UN being postponed for many years. ${ }^{31}$

When Communist China entered the Korean War, the Kuomintang, which fully supported the US-led UN military operation (peacekeeping), not only continuously provoked at the Security Council, but also presented false documents about the MPR - described as "a Chinese territory seized by the Soviet Union" - sending troops to North Korea. Meanwhile, in the 1950s McCarthyism was rife in the United States accusing many of "losing" China to Communism.

Due to the Baitag Bogd border incident, Mongolia and ROC had no diplomatic ties in 1946-1949. It was only in 1949 that diplomatic relations between the two countries (MPR and PRC) were established. On 12 February 1953 the ROC on Taiwan annulled the 14 August 1945 Sino-Soviet Treaty of Friendship and Alliance and its recognition of Mongolia's independence.

The Office of the Permanent Representative of the MPR was established in New York in December 1961. The first Permanent Representative (ambassador) of the MPR was ambassador Bayariin Jargalsaikhan. He presented his Letter of Credentials to the UN's Secretary-General, U Thant, on 15 December 1961.32

Finally,_firstly, many years of diplomatic efforts to join the United Nations have been successful, and Mongolia has became the $101^{\text {st }}$ membership of the international community, secondly, the country's independence and security have been assured by multi-parties, thirdly, coming out of isolation, making contributions in solving global issues, fourthly, the country has opened the wide way to go to cooperation with the world countries, and lastly, it began a period of diplomatic recognition of the country by western powers.

Moreover, during the Cold War the United Nations podium became sharp arena of ideological struggle between the socialist-capitalist two systems led by the USSR and the USA, and Mongolia has been also involved.

Although, Post-Cold War, a new era of cooperation between Mongolia and the United Nations has began, and however, this is a completely different story.

\footnotetext{
31 Ulambayar D. "The Role of the Mongolian People's Republic in the Korean War"-European Journal of Korean Studies. Volume 18. No.1 (2018), pp. 97-129

32 ГXТА. http://mfa.gov.mn/37073
} 


\section{References}

Central Archives of Foreign Affairs, Mongolia. Fond.5

Documents for the Foreign Policy of the MPR (1961-1961) Volume I, UB.: 1964

The United Nations and Mongolia. Documents from the UN and Government Archives.

(Collected Documents) UB.: 2008 (in Mongolian)

FRUS. 1947, Vol. I, 1949, Vol. II, UN, 1955-57, Vol. XI

FRUS. 1961, UN, 1961-63, Vol. XXII

Resolutions and Decisions adopted by the General Assembly during its 10th session:

GA Official Records, 10th session, Supplement No. 19 Resolutions and Decisions, 20 September - 20 December 1955: $\underline{\mathrm{A} / 3116}$

Presidents of the Security Council : 1960-1969, un.org.

Церенцоодол П. Монгольская Народная Республика и Организация

Объединённых Наций. УБ., 1958

XXII, Официальные отчёты Генерального Ассамблея: XVI сессия пленарного заседания (1-11). Стенографические отчёты заседания, Нью Йорк.: 19 октября-15 декабря 1961

Yi. Zhang. "The Cold War and the UN Membership of the Mongolian People's Republic". East Asia 32 (2), June 2015, pp. 207-221

Bold R. Mongolian Independent and the USA (1910-1973). UB.: 2008, pp. 264-269 (in Mongolian)

Lkhamsuren N. Memory: Independence of the Motherland - Newspaper "Mongolian Worker", August 20, 1990 (in Mongolian)

Ulambayar D. "The Role of the Mongolian People's Republic in the Korean War"European Journal of Korean Studies. Volume 18. No.1 (2018), pp. 97-129

Ulambayar D. «Mongolian-Turkish Relations: From De Facto till De jure»-Journal of East Asian Studies in Türkiye Doğu Asya Araştırmaları Dergisi. 土耳其东亚研 究学刊 DAAD GÜZ Fall 2020 (in turkish, english \& chinese) ISSN: 2587-1919, E-ISSN:2619-953X impact factor journal. pp. 131-147

Ulambayar D. Foreign Relations between Mongolia and West: Past and Recent. UB.: 2004 (in Mongolian) 